\title{
ZU ALT- UND MITTELENGLISCHEN DICHTUNGEN. \\ XII.
}

60. Salomo und Saturn.

Die neue ausgabe von Assmann-Wülker im 3. bande der 'Bibliothek der ags. Poesie' s. 304 ff. giebt mir zu einigen kritisch-exegetischen bemerkungen veranlassung.

v. 11. elnes oððe áhte eorlscipes

Das metrum und der sinn verlangen die einsetzung von oððe vor eorlscipes; vgl. auch den vorhergehenden vers!

v. 34. Fracođ hé bið đonne 7 fremede fréan olmintizum. Das metrum verlangt natürlich oelmihtzun.

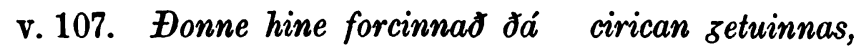
$N 7 \mathrm{sa}[\mathrm{m}] \circ d$ : ázhwoeðer brenzeð

Grein erklärt im Sprachschatz einleuchtend forcinnað als lesefehler für forcumað; aber auch cirican kann nicht richtig sein. Mit bezug auf v.119, wo die buchstaben $Q$ und $U$ als frome folctozan bezeichnet werden, möchte ich cirican in cinlican = cynlican bessern. - Trotzdem Sievers die korrektur Greins: $N 7$ [O] für 'metrisch falsch' erklärt hat, behält sie der neue herausgeber ruhig bei! Das einfachste ist, statt 7 (=ond) das fehlende $O$ einzusetzen, wobei wir mit umstellung den tadellosen halbvers $O, N$ samod erhalten.

v. 163. méces márðo: forðon nóniz man scile oft orðances út abrédan

Man erstaunt, wenn man in den anmerkungen liest, dass schon Grein richtig scile (= scyle) zu v. 163 gezogen hat. Warum der herausgeber diese einzig richtige versabteilung aufgegeben, ist um so unverständlicher, als das vorwort 'möglichstes fest- 
halten an Greins text als prinzip dieser neubearbeitung angiebt. - Auch v. 16 ist die richtige wortfolge: zebrydded sí, die Rieger hergestellt hatte, nicht in den text gesetzt.
v. 167. Páter noster 7 doet Palmtréow biddan mid blisse, etc.

Der sinnlose und metrisch falsche vers 167 ist nach v. 39 leicht herzustellen: man lese zepalmtwizede statt Palmtréow!

v. 180. módzléawe men middanzeardes ráswum zewesan ymbe hira wisdóm: etc.

Der erste vers ist offenbar zu lang; ráswum gehört wohl zu einem zwischen v. 180 und 181 fehlenden langvers.

v. 213. Fílistina, fréond Nebrondes. Grein hat richtig erkannt, dass in Nebrondes der hebr. Nimrod steckt; ich meine, dass wir dafür auch wirklich Nembrodes zu schreiben haben, vgl. foeder Nebróðes, wie Cosijn und Sievers Beitr. XIX, 450 das sinnlose faderne breder Gen. 1628 scharfsinnig verbessert haben. Sollte übrigens nicht auch hier Nembrodes zu lesen sein?

$$
\begin{aligned}
& \text { v. 235. weallas blícan } 7 \text { hiera winrod lixan, } \\
& \text { sóðfoestra sezn? etc. }
\end{aligned}
$$

Grein fasst winrod als wyn-ród 'crux laetifica', wovon der acc. natürlich -róde heissen müsste!! Es ist wohl bloss für wuldor (einsilbig) verschrieben. Vgl. darüber Sievers, Beitr. X, 482, Anm. 1.

v. 251. Jaet mé zeséme snoterra monn.

Das metrum verlangt snotterra, vgl. Sievers, Beitr. X, 508 .

v. 276. Joet hine sé módeza heht Mélotes bearn Lies módza.

v. 286. ac him on hand zஷ́ð heardes 7 hnesces.

Der herausgeber erwähnt nicht, dass Rieger in der Z.f. d. $\mathrm{Ph}$. VII, 11 richtig zanzeð für zǿठ fordert, das übrigens auch in unkontrahiertes z๕écð gebessert werden kann.

v. 309. mid ðá frácnan féonde tó willan.

Der erste halbvers ist unvollständig und vielleicht nach Gen. $689 \mathrm{zu}$ mid ðá frécnan [fyrd] zu ergänzen.

v. 337. nerzend of niehtes wunde? Ac saze mé, hwoet noerende wóron!

Grein hat im Sprachschatz s. 290 noerende mit fragezeichen als negiertes part. präs. von wesan erklärt (vgl. den artikel 
neom), was doch schwerlich angseht. Sollte nicht nearwende dafür zu lesen sein? Der sinn ides verses bleibt mir allerdings dunkel.

v. 339. scíre zeondscinan? forhwám besceadeð héo Das metrum verlangt besceadwed; vgl. Sievers, Beitr. X, 506.

v. 394. neahtes ne $\delta \dot{y} \delta$ ccrcefte týd.

Dieser ganz unmögliche vers ist wohl so herzustellen: neahtes ne $\delta \hat{y}[e] \delta, \quad[$ inearo-]crcefte týd.

v. 463. 7 him bebéad bearn heofonwara.

Ich ergänze diesen mangelhaften vers durch einschiebung von bealu, acc. pl. n. des adj. (gehörig zu bearn) nach him.

v. 475. Is Jonne on Jisse foildan fíra ániz eorðan cynnes, ठárra đe man áze, déađ abóde, cér se: daez cyme, Joet sie his cálendcwiide arunnen.

Statt man in v. 476 ist wohl miit Bouterweck áðm oder ein synonymer ausdruck (z. b. oroð) zu setzen; vor déað v. 477 gehört ein relatives $\partial e ;$ v. 478 ergänze ich das adv. cláne vor arunnen.

v. 480. ‘ázhwylc[um men $\|$ e]mzel onsended dryhten he ....... etc.

Mit onsended ist offenbar die exrste langzeile $\mathrm{zu}$ ende und dryhten he . . . ist der anfang desr zweiten.

Gotenburg, 2. September 18999.

\section{Generydes ed. Wright.} E. E. T. S., 0. \$S. 55 u. 70.

Bereits in „Göteborgs högskolias festskrift, tillägnad konsul 0. Ekman", Göteborg 1898 habe jich beiträge ') zur textkritik dieser romanze veröffentlicht, die ssich auf die ersten 2869 verse beziehen. Ich lasse hier den schliuss folgen und hoffe dadurch die wertvollen arbeiten von Zupittza (Anglia 1, 481 ff.), Zirwer (Engl. Stud. 17, 23 ff.) und Kölbingg (ib. 49 ff.) nicht unwesentlich zu ergänzen. Eckige klamımern bedeuten ergänzungen, runde dagegen vorgeschlagene auslassungen.

1) Als sonderabdruck ist meine ablhandlung bei Wettergren \& Kerber mit dem titel: „Beiträge zur textkritik der mittelengl. Generydes-romanze (ed. Wright)" erschienen. 
v. 2871. And whanne [that] they were all to-geder mett.

v. 2874. Thanne was ther Ioy [ful gret], I yow be-hight. K. will [grete] Ioy lesen, was einen schlechten vers ergiebt.

v. 2891. And to the kyng he spake in (e)speciall.

v. 2894. To (di)stroye the Cite (it) is noo grete empri[se]. $\mathrm{K}$. druckt als besserung: (To di)stroye, was aber wohl nur ein versehen ist; er hat auch schon richtig it getilgt, aber das von Wr. aus entrepri ergänzte schlusswort des verses nicht beanstandet. Entreprise jedoch überfüllt den vers, weshalb ich emprise dafür vorschlage. Wenn man town statt cite schreibt, kann it übrigens bleiben.

v. 2911. For in wurchippe and (in) knyghtoode sekerly.

v. 2941. Thanne the kyng of Trace putt hymself in prese. Zi. setzt richtig Grece für Trace ein, doch verlangt der rhythmus auch noch, putt vor the kyng zu stellen.

v. 2963. Abell that was of Perse the ban[y]ere.

Diese in v. 2014 überlieferte form des wortes ist auch v. 2105, 2128 und 2213 einzusetzen; im letzteren ist Ser zu streichen und that vor was zu ergänzen, wodurch er $=$ v. 2963 wird. Hierdurch erledigt sich mein vorschlag in der genannten festschrift. In v. 2055 lautet die form baneer.

v. 2977. And many [a] lorde [wa]s slayn on euery side.

v. $3009 \mathrm{f}$. Whom that euer he mette vppon the grene, [Down] from his sadill he wente quyte and clene. Im ersten verse stelle ich um: he euer und im zweiten, nach ergänzung von down: wente he.

v. 3013. Eche for his parte [a]quyte hymself full wele.

v. 3020. Ther wepons fowle [were] and [right] ill faryng. $\mathrm{K}$. hat schon richtig were ergänzt.

v. 3052. And claue his hede streyte down [on]to the brest.

v. $3119 \mathrm{ff}$. his land and [eke] hymself where ener hee goo, and [as] for the accompleshment also,

Because I wold (that) it shuld be endid sone.

$\mathrm{K}$. hat schon richtig v. 3119 land in men gebessert.

v. 3130. [And] for this cause he gaue sone his assentt.

v. 3146. In token of pece [did take] for ther viage.

Kölbings tok genügt nicht! 
v. 3161. Betwix them (bothe) myght the souner haue end[yng]. Wr. hat des reimes wegen an end in endyng gebessert, doch ist auch bothe $\mathrm{zu}$ streichen.

v. 3189. (And) my moder is a quene in certayn[te]. Certaynte ist schon von Wr. gebessert.

v. 3195. Thanne was he gladde and verily (well) content.

v. 3277. Whanne he departid (ther) was grete hevynes.

v. 3291. Kyng Béllyn rideth (in) to the feld alone.

v. 3320. And in like wise the citezens (euer)ychon.

v. 3341. (Thu shallt wele) knowe that I am not come[n] on massage.

v. 3375. 'I know', quod he, 'that on lyve I may skape. Lies: that $I$ on lyve.

v. 3390. Full hevy was Clarionas (thanne) also.

v. 3407. And after gaue it (on) to Generides.

v. 3461. He lay not long but riseth fayre and still. Der reim auf fell verlangt well statt still.

v. 3463. To kyng Bellyng, and toke hym be the reyne. Der könig heisst sonst Bellyn, Belyn, Belen, Belleyn etc., stets ohne $g$ am ende.

v. 3484. For of his fayling ther he was full woo. Lies falling, vgl. v. 3476: and ther he lay.

v. 3485. Generides was noo thyng (ev)ill apayde.

v. 3523. And cleue his hede [a] down and hurt hym sore.

v. 3549. They mett hym all with a [right] hevy chere.

v. 3570. And thankid hym in full [e]speciall wise.

Schon Wr. hat specially in speciall gebessert.

v. 3591. The lordes all went home (in) to ther contré.

v. 3640. (And) peraventur souner so may it be.

v. 3698. Be-cause ye knowe so will this [your] contré.

Die ergänzung ist nicht ganz sicher, aber ein einsilbiges wort fehlt gewiss; will ist $=$ well.

v. 3717. (Ser) Iuell the knyght came in-to the Citee.

v. 3786. Secré[t]ly, that no man [may] yow aspye.

v. 3844. To the cité streight he toke the waye. Lies anon statt streight.

v. 3847. Of ser Yuell and (of) fayre Clarionas.

v. 3859. [And] all these thoughtez, late them ouer-slide! 
v. 3863. To ser Yuell [full] streight uppon the felde.

v. 3887. As for this day to travell more and lesse.

Lies or statt and.

v. 3920. In his harnes slepyng [full] still opece.

v. 3923. Rememb[e]ryng the seruice day by day.

v. $3937 \mathrm{f}$. Owt of the logge, [as] she sleppe still alway, And to (ser) Yuell delyueryd hir ageyn.

v. 3948. Butt al [a]way he led (fayre) Clarionas.

Schon K. hat $a[$ way] ergänzt.

v. 3960. Of Mirabell [full] sone he had a sight.

v. $4007 \mathrm{f}$. [And] Mirabell thanne made noo taryeng, Butt to the sowdon (she) toke the [redy] waye.

$\mathrm{K}$. will right vor waye ergänzen. Vgl. zu meiner besserung v. 3706 !

v. 4025. And brought fro yow a streyt comaund[e]ment.

v. 4031. And nere [was] nyght, wherefore he thought it best.

v. 4049. Aftur (ser) Yuell Generides is goo.

v. 4051f. And as for yow, to take the enterprise, It shall [not] nede, if his liff may endure.

Durch diese einfache ergänzung erledigen sich Kölbings besserungsvorschläge $\mathrm{zu}$ den beiden versen.

v. 4059. Thanne seid he (this) to Mirábell: 'I you prae.

v. 4071. And to the Citee-ward the Sowdon ganne hym dresse. Lies he statt the sowdon. Soll letzteres bleiben, dann ist citee-ward durch town $\mathrm{zu}$ ersetzen.

v. 4099. $X V$ tymes she swounyd in his sight. Lies: she swounyd $X V$ times.

v. $4119 \mathrm{f}$. Owt of dangér I wold be (and) in sureté? 'Sureté?' quod he, 'drede yow no maner thyng!' Bei setzung des fragezeichens hinter surete ist es unnötig, dies wort mit K. in surely zu ändern. Statt yow lies ye.

v. 4162. By fortune suche (before $w$ )as neuer sene. Da die reimwörter certayn und trayn sind, haben wir statt sene wohl shall come agein $\mathrm{zu}$ schreiben. (Fortsetzung folgt.)

Go'renburg, 4. Oktober 1899.

F. Holthausen. 